\title{
Wiedza mieszkańców gminy Lipno na temat raka jelita grubego
}

\author{
Knowledge of the inhabitants of the Lipno \\ commune about colorectal cancer
}

\section{MARIOLA RYBKA ${ }^{1}$, AGNIESZKA STRUŻYŃSKA ${ }^{2}$}

${ }^{1}$ Państwa Uczelnia Zawodowa we Włocławku, Szpital Lipno Sp. z o.o. Zakład OpiekuńczoLeczniczy

${ }^{2}$ WIMED Poradnia Lekarza POZ w Lipnie

DOI: http://dx.doi.org/10.21784/IwP.2020.019

ISSN: 2451-1846

\section{Streszczenie}

Wstęp. Rak jelita grubego należy do najczęściej występujących nowotworów przewodu pokarmowego niezależnie od płci. Najczęściej dotyczy obszaru odbytnicy. W Polsce dynamika zachorowań jest znacznie większa niż Europie. Obserwuję się wzrostową tendencję zachorowalności i umieralności wśród populacji na raka jelita grubego.

Cel. Celem badań było poznanie poziomu wiedzy mieszkańców gminy Lipno na temat raka jelita grubego oraz zakresu nawyków zdrowotnych

Materiał i metody. Badania przeprowadzono na grupie 100 respondentów z terenu gminy i miasta Lipna. Respondenci byli zróżnicowani pod względem wieku, płci, wykształcenia i miejsca zamieszkania. Do oceny zastosowano kwestionariusz ankiety konstrukcji własnej oraz kwestionariusz IZZ.

Wyniki. Grupę badanych stanowiło 100 osób w tym 53\% stanowiły kobiety natomiast mężczyźni $47 \%$, średni wiek respondentów wynosił 44,6 lat. Średnia punktowa poziomu wiedzy badanych wyniosła - 5,82 punktu. Wynik wskazuje na niski poziom wiedzy. 
Wnioski. Przeprowadzone badania wykazały zróżnicowany poziom wiedzy respondentów oraz różne zachowania zdrowotne. Grupę badanych cechował niski poziom wiedzy na temat profilaktyki raka jelita grubego.

Słowa kluczowe: rak jelita grubego; wiedza; profilaktyka; zachowania zdrowotne.

\section{Summary}

Introduction. Colorectal cancer is one of the most common cancers of the gastrointestinal tract, regardless of gender. Most often it affects the rectal area. In Poland, the dynamics of morbidity is much greater than in Europe. There is an upward trend in the incidence and mortality of colorectal cancer among the population.

Aim. The aim of the research was to find out the level of knowledge of the inhabitants of the Lipno commune about colorectal cancer and the range of health habits.

Material and methods. The research was carried out on a group of 100 respondents from the commune and city of Lipno. The respondents were diverse in terms of age, sex, education and place of residence. A questionnaire of the own-made questionnaire and the IZZ questionnaire were used for the evaluation.

Results. The group of respondents was 100 people, $53 \%$ of whom were women, while men $-47 \%$, the average age of the respondents was 44.6 years. The point mean of the level of knowledge of the respondents was - 5.82 points. The result shows a low level of knowledge.

Conclusions. The conducted research showed a varied level of respondents' knowledge and different health behaviours. The group of respondents was characterized by a low level of knowledge about the prevention of colorectal cancer.

Keywords: colorectal cancer; knowledge; prevention; health behaviour. 


\section{Wstęp}

Rak jelita grubego (okrężnicy) jest nowotworem złośliwym umiejscowionym w obrębie odbytnicy, okrężnicy, zgięcia esico-odbytniczego. Do jego rozwoju dochodzi w wyniku rozrostu komórek w obszarze jelita grubego najczęściej pod postacią łagodnego polipa-gruczolaka, który po wielu latach dochodzi do powstania nowotworu złośliwego $[1,2]$. Do czynników ryzyka zachorowania na raka jelita grubego zaliczamy: genetyczne obecność raka jelita grubego wśród rodziny 1 stopnia, w wywiadzie polipowatość, przewlekłe stany zapalne jelitchoroba Leśniewskiego-Crohna, wrzodziejące zapalenie jelit, otyłość, nadwaga, wiek -głównie 7-8 dekada życia, brak aktywności, płeć męska, rasa biała $[3,4]$. Do istotnych czynników zaliczamy styl życia: złe nawyki żywieniowe- dieta uboga w błonnik, duża zawartość cukru i tłuszczów, pokarmy wysoko przetwarzane, palenie tytoniu, alkoholizm [5]. W Polsce obserwujemy systematyczny wzrost zachorowalności, Dotyczy najczęściej mężczyzn w weku powyżej 60 r.ż., [6]. Do charakterystycznych objawów zaliczamy stolec ołówkowy, biegunki na zmianę z zaparciami często pojawiają się wymioty, nudności, krew w stolcu [6]. Diagnostyka opiera się o wywiad, badanie fizykalne per rectum, kolonoskopię, rektoskopię, badanie występowania krwi utajonej w kale, badanie antygenu CEA (karcynoembrionalnego) we krwi. [7].

W leczeniu nowotworu jelita grubego stosuje się różne formy terapii. Dobór procesu terapeutycznego uzależniony jest od wielu czynników związanych m.in. od umiejscowienia guza, zaawansowania raka, aktualnego stanu fizycznego pacjenta, decyzji chorego.[8]. Leczenie chirurgiczne jest fundamentem postępowania terapeutycznego $\mathrm{u}$ pacjenta z postawioną diagnozą rak jelita grubego. Ponadto zostaje wdrożone postępowanie uzupełniające czyli skojarzone z radioterapią i chemioterapią, dootrzewnową chemioterapią perfuzyjną w hipertermii (DCPH) . 
Wielu pacjentów podczas zabiegu chirurgicznego ma wyłonioną tzw. stomię, może ona być rozwiązaniem ostatecznym lub przejściowym w celu wygojenia zespolenia. Rokowanie u pacjenta $\mathrm{z}$ rakiem jelita grubego jest uzależnione poziomu na jakim jest rozpoznany rak oraz od szybkości rozwoju raka. Perspektywa przetrwania to okres 5 lat od chwili zdiagnozowania choroby $[9,10]$.

Jednym z najistotniejszych działań w profilaktyce raka jelita grubego są działania z obszaru przeciwdziałania rozwijaniu się choroby, a dotyczy to spożywania produktów zawierających błonnik, uprawiania sportu, spożywania warzyw i owoców ograniczenia podaży produktów przetworzonych, picia płynów wysokoprocentowych [11]. Kolejny etap to badania przesiewowe/skryningowe czyli kolonoskopia u osób po 50 r.ż. co 10 lat, co 5 lat kontrastowe badanie jelita grubego oraz sigmoidoskopia, a raz $\mathrm{w}$ roku test na obecność krwi utajonej w kale.

Badania przesiewowe w przypadku nowotworu jelita grubego są metodą o dużej skuteczności. Pomimo szerokiej dostępności do badań jak i dobrych wyników leczenia z tytułu skutecznej i szybko wdrożonej terapii znaczna część naszego społeczeństwa niechętnie uczestniczy. Uwidacznia się to głównie wśród osób zamieszkujących małe miejscowości, gdzie wiedza odnośnie profilaktyki, czynników ryzyka jest niewystarczająca, a ilość osób wykonujących badania przesiewowe jest zbyt niska.

\section{Cel}

Celem badań był poznanie poziomu wiedzy mieszkańców gminy Lipno na temat raka jelita grubego, realizowanych działań z obszaru profilaktyki, zachowań zdrowotnych, uczestnictwa w badaniach przesiewowych. 


\section{Materiał i metody}

Narzędziem badawczym niniejszego badania był kwestionariusz ankiety konstrukcji własnej. Zawierał on 27 pytań, w tym 23 pytania zamknięte, 4 pytania otwarte. Wykorzystano także kwestionariusz IZZ (Inwentarz Zachowań Zdrowotnych), który obejmuje 24 postawy związane ze zdrowiem: zachowania zapobiegawcze, działania zdrowotne, przyzwyczajenia żywieniowe, korzystne podejście psychiczne. Na skorzystanie z IZZ otrzymano zgodę z Pracowni Testów Psychologicznych.

Uczestnikami badania było 100 pacjentów objętych opieką lekarza rodzinnego przez Niepubliczny Zakład Opieki Zdrowotnej „WIMED” w Lipnie. Badania przeprowadzono w okresie od grudnia 2019r. do końca stycznia 2020. Na przeprowadzenie badań uzyskano zgodę Komisji Bioetycznej przy Państwowej Uczelni Zawodowej we Włocławku. Analiza opisowa otrzymanych wyników to liczebność, procentowość, średnia wraz z odchyleniem standardowym. Współzależność pomiędzy dwiema zmiennymi, obliczono za pomocą współczynnik korelacji R Spearmana. Zastosowano również, nieparametryczny Test U Manna-Whitneya, do oceny różnic jednej cechy pomiędzy dwoma populacjami (grupami) oraz nieparametryczny Test rang Kruskala-Wallisa.

\section{Wyniki}

Średnia wieku badanych to - 44,6 lat. Odchylenie standardowe stanowiło 36,3\% wartości średniej, co świadczy o znacznym zróżnicowaniu wiekowym. Średnio kobiety były starsze od mężczyzn, ze średnią - 45,4 lat, przy średniej mężczyzn - 43,7 lat. Wiek minimalny 18 lat, maksymalny 89 lat. Respondentów podzielono na cztery, zbliżone liczebnie grupy wiekowe: 18-30 lat, 31-50 lat, 51-60 lat oraz $>60$ lat. Najliczniejszą grupę stanowili badani w wieku 31-50 lat - 38,0\%, najmniej liczną w wieku 51-60 lat i >60 lat - po 19\%. Uczestnicy badania porównywalnie zamieszkiwali tereny miejskie $52,0 \%$ oraz tereny 
wiejskie $48 \%$. Co do wykształcenia to dominowało wykształcenie zawodowe i średnie - po 31,0\%, oraz porównywalne wyniki stanowiły osoby z wykształceniem podstawowym $-18 \%$ oraz wyższym $18 \%$, najmniej respondentów posiadało wykształcenie gimnazjalne - 2,0\%. Co do zmiennej demograficznej stan cywilny to najliczniejszą grupe stanowili respondenci pozostający w związku małżeńskim - 43,0\%. Najmniej liczną grupą były osoby samotne $-9,0 \%$. Dość liczną grupę stanowiły osoby będące z wyboru single $25 \%$. Respondenci zakres swojej wiedzy dotyczący chorób dolnego odcinka przewodu pokarmowego określili jako dobry-18,0\%, jednak niepokojące jest to, że nie $58,0 \%$ wskazało na brak wiedzy. Źródłem wiedzy na temat raka jelita grubego był najczęściej internet - 67 osób, co stanowiło 28,3\%, 13,9\% respondentów wskazało na telewizję/ radio na rodzinę wskazały - 33 osoby (13,9\%). Respondenci mieli możliwość wskazania na wybrane dolegliwości ze strony układu pokarmowego z ukierunkowaniem na objawy wrażliwe w kierunku raka jelita grubego. Większość badanych wskazała, że nie odczuwa dolegliwości ze strony przewodu pokarmowego- 83,0\%. Jednak - 7 osób wskazało na bóle brzucha, 6 osób wzdęcia, zaparcia wystąpiły u 5 osób, biegunki - 5 osób, na zgagę uskarżały się 3 osoby oraz kolki, nadkwaśność, uczucie pełności, częste wypróżnianie i okresowo nudności - po 1 osobie. Do czynników sprzyjających rozwojowi raka jelita grubego zdecydowanie respondenci wskazali na obciążenia genetyczne - 76 osób, co stanowiło $23,3 \%$ wszystkich odpowiedzi.

Kolejnym czynnikiem była polipowatość jelit i nieprawidłowe odżywianie - po 49 osób (po 15,0\%) oraz hemoroidy - 42 osoby $(12,9 \%$ ). Najmniej osób wskazało na niską aktywność fizyczną - 22 osoby (6,7\%). Respondenci rozumieją czym jest badanie przesiewowe poprawną odpowiedź udzieliło - 88,0\%. Jednak niepokojące jest to, że 93\% badanych wskazało, że nie robiło badań przesiewowych w kierunku 
raka jelita grubego. Podjęto próbę ustalenia oceny poziomu wiedzy na temat raka jelita grubego uzyskane wyniki przedstawia ryc. nr 1

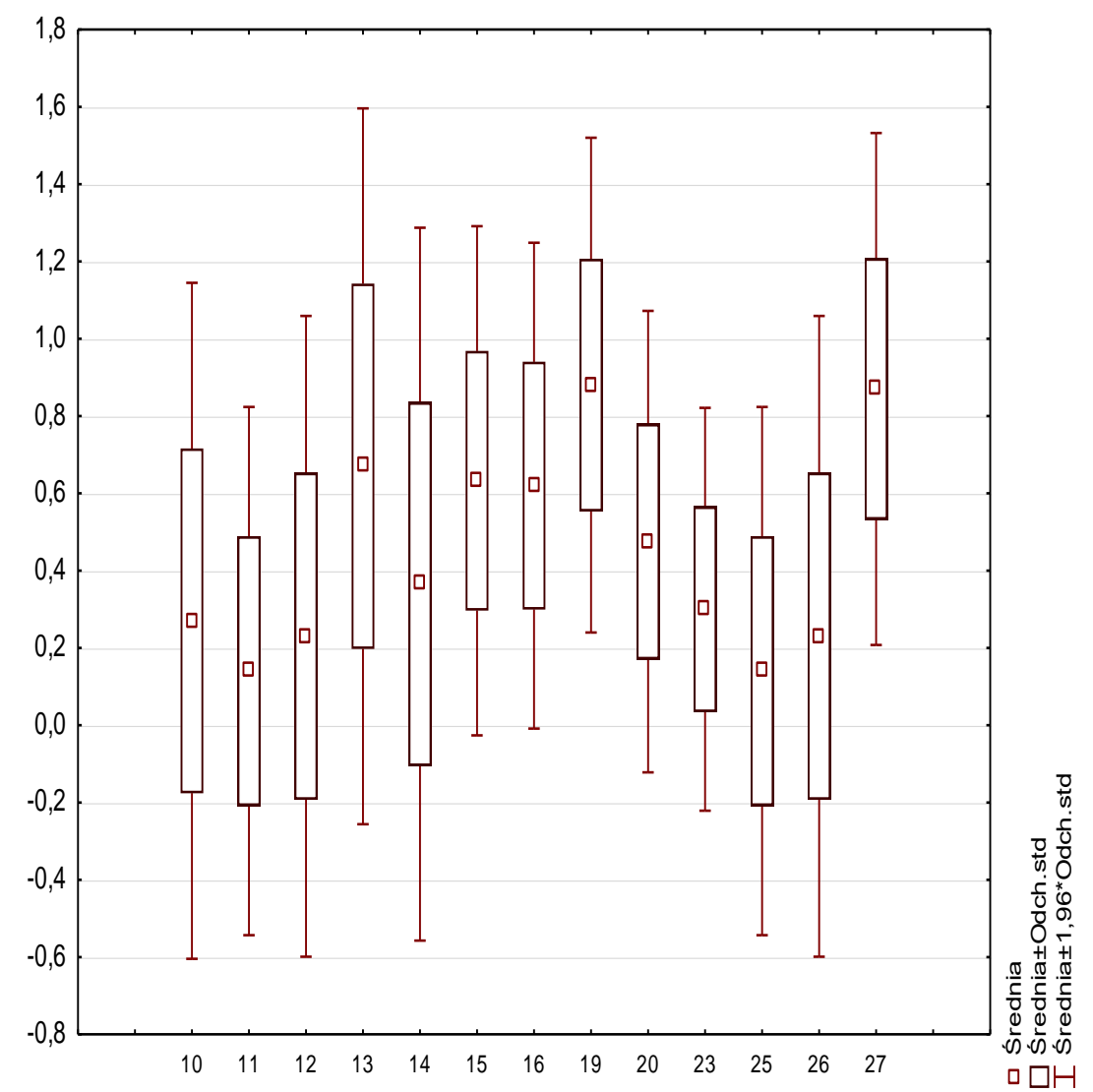

Ryc. 1. Zakres i poziom wiedzy na temat czynników ryzyka jak i objawów oraz badań profilaktycznych

Najwyższą średnią odnotowano w pozycjach: rozumienie pojęcia badania przesiewowe (19) - 0,88 punktu, czy według Pana/i wczesne rozpoznanie rjg ma wpływ na efekt terapeutyczny (27) - 0,87 punktu, kto częściej choruje na raka jelita grubego (13) - 0,67 punktu oraz 
czynniki przyczyniające się do rak jelita grubego (15) - 0,63 punktu. Najniższe średnie wyniki odnotowano w pozycjach: czy płeć zwiększa ryzyko zachorowania na raka jelita grubego (12) - 0,23 punktu, częstość z jaką powinno być wykonywane badane kolonoskopii w przypadku osób obciążonych ryzykiem zachorowania na rjg (26) - 0,23 punktu, czy wiek ma wpływ na występowanie raka jelita grubego (11) - 0,14 punktu oraz częstość z jaką powinno być wykonywane badane kolonoskopii w przypadku osób zdrowych (25) - 0,14 punktu. Średnia punktowa poziomu wiedzy badanych wyniosła - 5,82 punktu. Wynik wskazuje na niski poziom wiedzy.

Odchylenie standardowe stanowiło 31,6\% wartości średniej, co świadczy o znacznym zróżnicowaniu wyników. Wynik minimalny - 2,8 punktu i uzyskała go 1 osoba, maksymalny - 11,0 punktów i uzyskała go 1 osoba. Zmienne statystyczne jak wiek, płeć oraz miejsce zamieszkania nie miały wpływu na posiadany zakres wiedzy dotyczący raka jelita grubego. Istotą zależność zaobserwowano przy analizie wykształcenia. Najwyższy poziom wiedzy prezentowali badani $\mathrm{z}$ wykształceniem wyższym. Najniższy poziom wiedzy prezentowali badani $\mathrm{z}$ wykształceniem zawodowym. Wyniki średniego poziomu wiedzy 8 osób (24,2\%), przy najwyższym wskaźniku poziomu braku wiedzy 8 osób $(24,2 \%)$. Na poziom wiedzy istotny wpływ miał stan cywilny. Najwyższy poziom wiedzy prezentowali badani będący w związku małżeńskim. Najniższy poziom wiedzy prezentowały osoby wolne z wyboru.

Analiza danych uzyskanych na podstawie Inwentarza Zachowań Zdrowotnych $\mathrm{w}$ odniesieniu do prawidłowych nawyków żywieniowych, najwyżej oceniono: dbam o prawidłowe odżywianie - średnia 3,53 punktu oraz jem dużo warzyw, owoców - średnia 3,47 punktu. Najniżej unikam soli i silnie solonej żywności - średnia 3,25 punktu oraz ograniczam spożywanie tłuszczy zwierzęcych, cukru - średnia 3,2 punktu. Co do zachowań profilaktycznych, najwyżej oceniono 
pozycje: przestrzegam zaleceń lekarskich wynikających z moich badań - średnia 3,57 punktu oraz mam zanotowane numery telefonów do służb pogotowia - średnia 3,5 punktu. Najniżej, regularnie zgłaszam się na badania lekarskie - średnia 3,09 punktu oraz staram się dowiedzieć jak inni unikają chorób - średnia 2,97 punktu. W pozytywnym nastawieniu psychicznym, najwyżej oceniono pozycje: mam przyjaciół i uregulowane życie rodzinne - średnia 4,03 punktu oraz myślę pozytywnie - średnia 3,6 punktu. Najniżej, u staram się unikać zbyt silnych emocji, stresów i napięć - średnia 3,08 punktu oraz unikam takich uczuć jak gniew, lęk depresja - średnia 2,92 punktu. W praktykach zdrowotnych, najwyżej oceniono pozycje: ograniczam palenie tytoniu - średnia 3,52 punktu oraz unikam nadmiernego wysiłku fizycznego - średnia 3,39 punktu. Najniżej, kontroluje swoją wagę ciała - średnia 3,09 punktu oraz unikam przepracowania - średnia 3,07 punktu. Badani jako grupa prezentują przeciętny poziom prawidłowych nawyków żywieniowych, praktykach zdrowotnych, zachowań profilaktycznych, oraz pozytywnego nastawienia psychicznego. Średnia to 3,36 punktu.

Odchylenie standardowe wyniosło ponad $21,5 \%$ wartości średniej, co świadczy o przeciętnym zróżnicowaniu wyników. Ze względu na poziom istotności ( $\mathrm{p}>0,05)$, nie odnotowano istotnych statystycznie różnic pomiędzy kobietami i mężczyznami, dotyczących wyników IZZ i jego podskal. Wyższe wyniki punktowe zarówno zachowań zdrowotnych (IZZ) oraz prawidłowych nawyków żywieniowych, zachowań profilaktycznych i praktyk zdrowotnych odnotowano w grupie kobiet. Grupy wiekowe badanych, nie pozostawały w istotnej statystycznie korelacji z wynikami IZZ ora podskal ( $p>0,05)$.Najwyższy średni wynik punktowy zarówno zachowań zdrowotnych (IZZ) oraz zachowań profilaktycznych, pozytywnego nastawienia psychicznego i praktyk zdrowotnych odnotowano $\mathrm{w}$ grupie wiekowej $>60$ lat. W prawidłowych nawykach żywieniowych w wieku 31-50 lat. Najniższe wyniki zarówno zachowań zdrowotnych oraz podskal: prawidłowych nawyków 
żywieniowych i pozytywnego nastawienia psychicznego odnotowano w grupie wiekowej 51-60 lat, w zachowaniach profilaktycznych i praktykach zdrowotnych w wieku 18-30 lat. Najwyższy wskaźnik wysokich wyników zachowań zdrowotnych odnotowano w grupie wiekowej $>60$ lat - 9 osób (47,4\%), przy wskaźniku wyników niskich - 5 osób (26,3\%). Dalej w wieku powyżej 31-50 lat - 12 osób (31,6\%), wyniki niskie - 14 osób $(36,8 \%)$. Najniższy wskaźnik wyników wysokich odnotowano w wieku 51-60 lat - 3 osoby $(15,8 \%)$, wyniki niskie - 11 osób $(57,9 \%)$.

Ze względu na poziom istotności ( $\mathrm{p}>0,05)$, nie odnotowano statystycznie istotnych różnic pomiędzy grupami wiekowymi a miejscem zamieszkania, dotyczących wyników poziomu zachowań zdrowotnych i jego podskal. Wyższe wyniki punktowe zarówno zachowań zdrowotnych (IZZ) oraz pozostałych podskal z wyjątkiem prawidłowych nawyków żywieniowych, odnotowano w grupie mieszkańców wsi. Najwyższy średni wynik punktowy zarówno zachowań zdrowotnych (IZZ) jak i pozostałych podskal uzyskali respondenci z wykształceniem wyższym. Najniższe wyniki IZZ oraz podskal, odnotowano w grupie wykształcenia średniego. Ze względu na poziom istotności $(\mathrm{p}<0,05)$, odnotowano istotną statystycznie różnicę pomiędzy grupami stanu cywilnego dotyczącą wyników praktyk zdrowotnych. Najwyższy średni wynik punktowy zarówno zachowań zdrowotnych (IZZ) oraz pozostałych podskal odnotowano w grupie osób owdowiałych. Najniższe wyniki zarówno zachowań zdrowotnych oraz zachowań profilaktycznych i pozytywnego nastawienia psychicznego $\mathrm{w}$ grupie $\mathrm{w}$ grupie będących $\mathrm{w}$ wolnym związku, $\mathrm{w}$ pozostałych podskalach $\mathrm{w}$ grupie rozwiedzionych co przedstawia ryc. nr 2. 


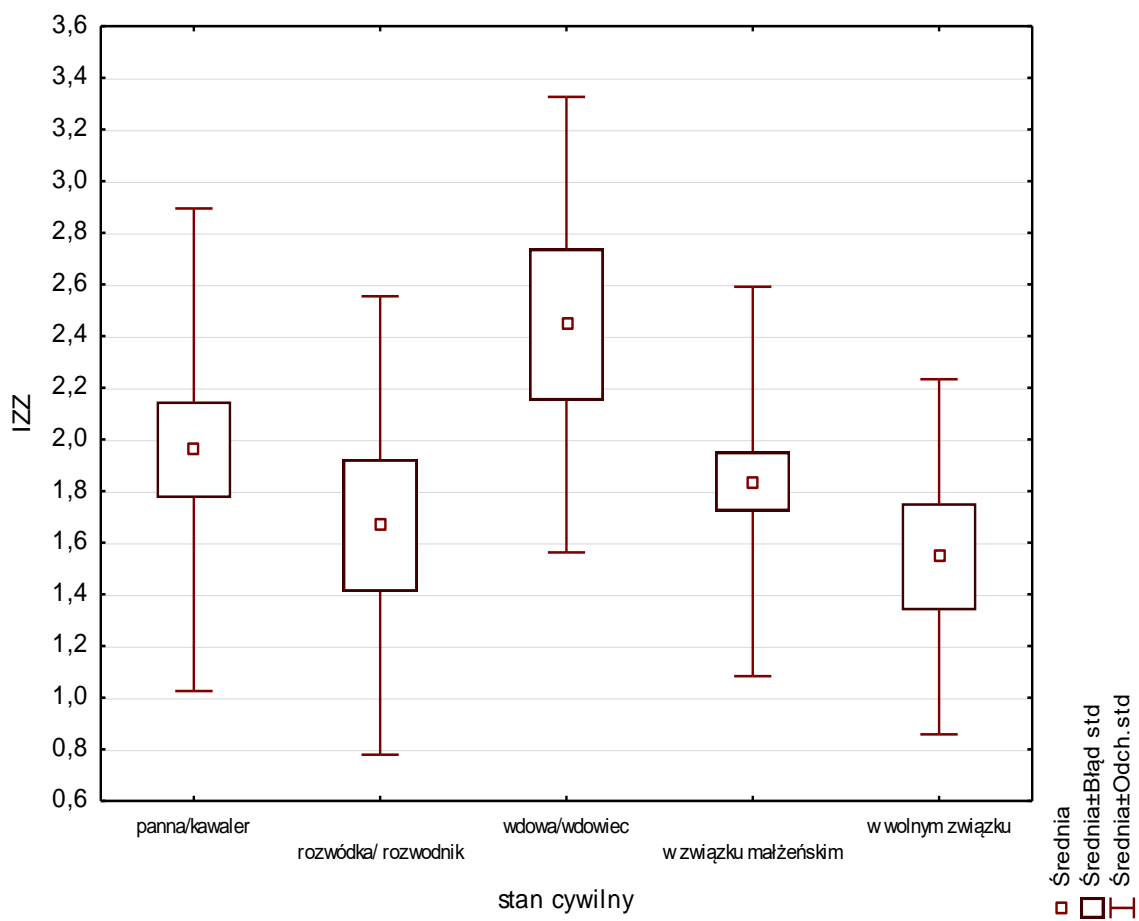

Ryc. 2. Rozkład wyników średnich IZZ w grupach stanu cywilnego.

Poziom wiedzy badanych, nie pozostawał w istotnej statystycznie korelacji z wynikami IZZ i jego podskal $(p>0,05)$.

\section{Dyskusja}

Kwestionariusz ankiety przeprowadzono pośród pacjentów Niepublicznego Zakładu Opieki Zdrowotnej „WIMED” w Lipnie. Chęć udziału w badaniach wykazali zarówno kobiety (53\%) jak i mężczyźni (47\%) w przedziałach wiekowych 18-30 lat (24\%), 31-50 lat (38\%), 51-60 lat (19\%), >60r.ż. (19\%). 52 osoby mieszkają w mieście, 48 osób jest mieszkańcami wsi. Najwięcej z grona respondentów posiadało 
wykształcenie zawodowe i średnie - po 31\%, najmniej wykształcenie gimnazjalne $2 \%$, natomiast podstawowe i wyższe po $18 \%$. Najliczniejszą grupę ankietowanych stanowiły osoby w związku małżeńskim $43 \%$, najmniejszą owdowiali 9,0\%, pozostali: panna/kawaler 25\%, rozwódka/rozwodnik 12\%, w wolnym związku 11\%. Dokonano oceny zachowań zdrowotnych za pomocą kwestionariusza IZZ (Inwentarz zachowań zdrowotnych).

Odnosząc się do sformułowanych problemów badawczych z przeprowadzonych badań uzyskane wyniki opisano i porównano z innymi wynikami.

Poziom wiedzy mieszkańców gminy i miasta Lipno na temat raka jelita grubego jest zróżnicowany w kierunku niskiego. Z grupy osób biorących udział $w$ badaniu najwyższy poziomem wiedzy na temat raka jelita grubego pod względem wieku były to osoby z przedziału wiekowego 31-50 lat przy poziomie braku wiedzy - $(13,2 \%)$. Biorąc pod uwagę wykształcenie najlepszy wynik otrzymali z wykształceniem wyższym. Z badań Kuprewicz i wsp. odnośnie wiedzy mieszkańców miasta i wsi na temat raka jelita grubego, wynika, że najliczniejszą grupę stanowiły osoby z niskim poziomem wiedzy - 58,9\% osób, poziom średni - 38,7\% osób, a wysoki zaledwie - 2,4\% osób [12]. Grys i wsp. w badaniach o wiedzy mieszkańców województwa świętokrzyskiego odnośnie rjg. osiągnęli średni poziom wiedzy ponieważ średnia uzyskana z wszystkich właściwych odpowiedzi wynosiła 61\%. [13]. Sapiełkin i Gotlib pośród 114 chorych biorących udział w programie badań przesiewowych w sferze raka jelita grubego, którzy zgłosili się do oddziału endoskopii na kolonoskopię zgodnie z zaleceniami lekarskimi, w swych badaniach na temat wiedzy o rjg. wykazali niski poziom wiedzy ankietowanych o leczeniu i profilaktyce nowotworów jelita grubego. [14]

Wśród respondentów najwyższy poziom wiedzy z zakresu raka jelita grubego wykazywali badani w wieku 31-50 lat. Porównywalne 
wyniki uzyskała Stefanowicz i współautorzy gdzie świadomość osób po 50 r.ż. w zakresie czynników ryzyka raka jelita grubego jest zdecydowanie wyższe $(94,4 \%)$, od osób z pozostałych grup wiekowych np. osoby >60 r.ż. trzy krotnie mniej znały czynników ryzyka(30,2\%). Uzyskane wyniki badań własnych wykazały, że najwyższym poziomem wiedzy wykazali się ankietowani z wykształceniem wyższym. Również uzyskane wyniki pokrywają się z wynikami innych autorów m.nin. Stefanowicz i wsp. osoby z wyższym wykształceniem $(84,8 \%)$ w stosunku do osób mających wykształcenie niższe $(54,1 \%)$ posiadają szersza wiedzę [15]. Analiza danych statystycznych uzyskany przez Markowską i wsp. pokazała różnicę między osobami z wykształceniem podstawowym, a wyższym ( $p=0,0482)$, zawodowym, a wyższym $(p=0,026)$. Respondenci z wykształceniem wyższym udzielali przede wszystkim prawidłowych odpowiedzi, zaś z podstawowym głównie odpowiedzi złych [16]. Respondenci zamieszkujący tereny miejskie prezentowali wyższy poziom wiedzy, od osób zamieszkujących tereny wiejskie. $\mathrm{Ku}$ prewicz i wsp. w swych badaniach na temat wiedzy o rjg. wskazały na niski poziom wiedzy mieszkańców wsi 53,9\% od osób zamieszkujących tereny miejskie. [12]. Również wyniki badań przeprowadzonych przez Stefanowicz i wsp. wykazują na wyższy poziom wiedzy z zakresu omawianego tematu mieszkańców miasta - 54\%, niż mieszkańców wsi - 39,6\%. [15]. Grys i wsp. w swych badaniach pozyskali ogólny poziom wiedzy z zakresu rjg., który dla mieszkańców miasta wyniósł 66\% - jest to poziom średni, a dla mieszkańców wsi $48 \%$ - jest to poziom niski [13]. W badaniach wykonanych przez Markowską i wsp. odnośnie oceny wiadomości pewnych grup społecznych o profilaktyce CRC po analizie uzyskano następujące wyniki: ankietowani z obszarów wiejskich wykazali się niskim poziomem wiedzy, natomiast mieszkańcy miast uzyskali średni poziom wiedzy[16]. Biorąc pod uwagę miejsce zamieszkania wyższy wskaźnik wysokich wyników IZZ uzyskano w grupie mieszkańców miasta (49,2\%), przy niższym wskaźniku 
wyników niskich - 18 osób (37,5\%). Również potwierdzają powyższą tezę badania Kuprewicz i wsp. z zakresu wiedzy o rjg. Największym poziomem IZZ wykazali się mieszkańcy miasta - 39,8\% osób, ankietowani mieszkający na wsi osiągnęli niższy wskaźnik - 34\% osób. Pod względem płci mężczyźni otrzymali niski wynik IZZ - 44,2\%, kobiety wysoki wynik IZZ -40,7\% [12]. Gromada i Kobos analizowali zachowania zdrowotne 160 mieszkańców wsi w sferze zapobiegania rjg. Ankietowani głównie w swych zachowaniach stronili od używek $(M=1,79)$ im starsi tym bardziej, rzadko podejmowali działania w zakresie żywienia $(M=2,68)$ i wysiłku fizycznego $(M=2,86)$. Osoby pracujące, z większym wykształceniem regularnie robiły badania profilaktyczne $(\mathrm{p}<0,05)$. Wśród respondentów kobiety okazywały większe zachowania zdrowotne od mężczyzn $\mathrm{w}$ rubrykach: badania profilaktyczne $(\mathrm{p}<0,0001)$, używki, odżywianie $(\mathrm{p}=0,0008)$ [17]

\section{Wnioski}

1. Wiedza mieszkańców gminy i miasta Lipno jest zróżnicowana. Respondenci zakres swojej wiedzy dotyczący chorób dolnego odcinka przewodu pokarmowego określili jako dobry- 18,0\%, jednak niepokojące jest to, że nie - 58,0\% wskazało na brak wiedzy

2. Istotną zależność zaobserwowano co do wieku badanych, osoby z przedziału wieku 31-50 lat posiadają znacznie lepszą wiedzę na temat czynników ryzyka raka jelita grubego od osób młodszych i starszych.

3. Z przeprowadzonych badań wynika, że wykształcenie jest czynnikiem, który różnicuje poziom wiedzy respondentów. Osoby posiadający wykształcenie wyższe prezentowali wyższy poziom wiedzy. Na poziom wiedzy istotny wpływ miał stan cywilny. Najwyższy poziom wiedzy prezentowali badani pozostający w związku małżeńskim. 
4. Zachowania profilaktyczne, na najwyższym poziomie są realizowane z zakresu przestrzegania zaleceń lekarskich - średnia 3,57 punktu.

\section{Zalecenia dla praktyki pielęgniarskiej}

Edukacja oraz profilaktyka jest jednym z głównych determinantów przeciwdziałania powstania raka jelita grubego. Zadaniem pielęgniarek jest stałe prowadzenie profilaktyki pierwszego rzędu podczas kontaktu z pacjentem.

\section{Bibliografia/Bibliography:}

1. Denys A. Zagrożenia zdrowia publicznego wybrane zagadnienia. Środowiskowe uwarunkowania rozwoju chorób. Wolters Kluwer 2014:102105.

2. Kreis M.E. Rak jelita grubego. Aktualności medyczne 2015;(1):4-7.

3. Dmowska-Pycka A., Adamiak K., Wiedza mieszkańców wsi na temat raka jelita grubego. Pielęgniarstwo XXI wieku 2015;1(50):36-37.

4. Wyrwicz L. Diagnostyka i leczenie na raka jelita grubego. Głos pacjenta onkologicznego 2015;1(11):4.

5. Woźniak I. Właściwe odżywianie w profilaktyce przeciwnowotworowej. Magazyn Pielęgniarki i położnej 2016;(3):5-6.

6. Pączka L., Mucha K., Foroncewicz B. Choroby wewnętrzne Podręcznik dla studentów pielęgniarstwa i położnictwa Wydawnictwo Lekarskie PZWL. Warszawa 2014;289-292.

7. Pazdur R., Wagman LD., Camphausen KA., Hoskins WJ. Nowotwory złośliwe: postępowanie wielodyscyplinarne - leczenie systemowe, chirurgia, radioterapia. Lublin: Czelej; 2012.

8. Zegarski W. Nowoczesne techniki leczenia raka jelita grubego. Aktualności medyczne 2019;(12):8-12. 
9. Rybka M., Haor B., Grabowska H., Kilańska D., Tarkowska M., Głowacka M., Opieka nad pacjentem leczonym chirurgicznie z powodu raka odbytnicy, Magazyn pielęgniarki i położnej 2018;(5):41.

10. Peng J., Shi D, Goodman KA., et al. Early results of quality of life for curatively treated rectal cancers in Chinese patients with EORTC QLQ-CR29. Radiat Oncol. 2011;6:93.

11. Kim Min Ki et al. Comparison of the effects of an ERAS program and a single-port laparoscopic surgery on postoperative outcomes of colon cancer patients. Scientific reports 2019;9(1):1-8.

12. Kuprewicz A., Krajewska-Kułak E., Trochimowicz L. Wiedza na temat raka jelita grubego i preferowane zachowania zdrowotne mieszkańców miasta i wsi. Pielęgniarstwo Chirurgiczne i Angiologiczne 2016;2(2):74.

13. Grys A., Czarnecka J., Sienkiewicz Z., Krupienicz A. Wiedza mieszkańców województwa świętokrzyskiego na temat raka jelita grubego. Pielęgniarstwo Polskie 2013;1(47):26.

14. Sapiełkin B., Gotlib J. Wiedza pacjentów oddziału endoskopii na temat profilaktyki i leczenia nowotworu jelita grubego. Pielęgniarstwo XXI wieku 2013;2(43):23-27.

15. Stefanowicz A., Kulik T.B., Skórzyńska H., Środa M. Wiedza o programie profilaktyki raka jelita grubego wśród osób w wieku 50-66 lat. Geriatria 2017;11:259-260.

16. Markowska A., Górka J., Grochans E., Szkup M. Ocena wiedzy wybranych grup społecznych na temat profilaktyki raka jelita grubego. Medycyna Ogólna i Nauki o Zdrowiu. 2016;Tom 22, Nr 4:303-306.

17. Gromada A.T., Kobos E. Zachowania zdrowotne mieszkańców wsi w zakresie profilaktyki jelita grubego. Pielęgniarstwo Polskie. 2018;(4): 372378. 